\title{
Characterization of Basic Education Teachers Based on the Social Cognitive Model of Job Satisfaction ${ }^{1}$
}

\author{
Maély Ferreira Holanda Ramos ${ }^{2}$ \\ Universidade Federal do Pará, \\ Belém-PA, Brazil \\ Fernando Augusto Ramos Pontes \\ Universidade Federal do Pará, \\ Belém-PA, Brazil \\ Simone Souza da Costa Silva \\ Universidade Federal do Pará, \\ Belém-PA, Brazil
}

\author{
Edson Marcos Leal Ramos \\ Universidade Federal do Pará, \\ Belém-PA, Brazil \\ Daniela Couto Guerreiro Casanova \\ TSC Centro de Estudos e Pesquisas, \\ Bragança Paulista-SP, Brazil \\ Roberta Gurgel Azzi \\ Universidade Estadual de Campinas, \\ Campinas-SP, Brazil
}

\begin{abstract}
Teachers' job satisfaction and the factors that contribute to it are important in the school context as theycanaffect teachers' motivation and performance. This study aims to identify the dimensions associated with the degree of satisfaction amongbasic education teachers based on the Social Cognitive Model of Teacher Job Satisfaction and the degree of collective teacher efficacy. This study applied quantitative research methods to a sample of 495 basic education teachers within a network of private schools in three Brazilian states. The results indicate that positive affect and life satisfaction were the factors most strongly associated with job satisfaction. There was no association between efficacy beliefs (self-efficacy and collective efficacy) and job satisfaction. Elementary school teachers had the most negative perceptions of teaching. Specific aspectsof the school environment, such as a lack of student discipline, may have contributed to this result.
\end{abstract}

Keywords: job satisfaction, social cognitive theory, teachers

\section{Caracterização de Docentes da Educação Básica a partir do Modelo Social Cognitivo de Satisfação no Trabalho}

\begin{abstract}
Resumo: A satisfação no trabalho docente e seus elementos influenciadores são fatores importantes no contexto escolar, pois podem afetar os estados motivacionais e o nível de desempenho do professor. Este estudo tem como objetivo identificar as dimensões associadas ao grau de satisfação de professores da Educação Básica, a partir do Modelo Social Cognitivo de Satisfação no Trabalho Docente, e ao grau da eficácia coletiva docente. Consta de uma pesquisa quantitativa aplicada numa amostra de 495 docentes da Educação Básica de uma rede privada de ensino, em três estados brasileiros. Os resultados indicaram que o afeto positivo e a satisfação com a vida foram os fatores mais fortemente associados à satisfação com o trabalho. Não houve associação entre as crenças de eficácia (auto eficácia e eficácia coletiva) e a satisfação no trabalho. Os professores do Ensino Fundamental apresentaram as percepções mais negativas sobre a docência. Circunstâncias específicas do contexto escolar, tais como a indisciplina discente, podem ter contribuído para esse resultado.
\end{abstract}

Palavras-chave: satisfação no trabalho, teoria social cognitiva, professor

\section{Caracterización de los Docentes de Educación Básica a partir de la Satisfacción del Modelo Social Cognitivo Social en el Trabajo}

\begin{abstract}
Resumen: La satisfacción en el trabajo y sus elementos de influencia, son factores importantes en el contexto escolar, porque pueden afectar los estados de motivación y el nivel de desempeño del docente. Este estudio tiene como objetivo identificar las dimensiones asociadas al grado de satisfacción de los profesores de Educación Básica, a partir del Modelo Social Cognitivo de Satisfacción en el Trabajo y el grado de eficacia colectiva docente. Asimismo, constituye una investigación cuantitativa aplicada a una muestra de 495 docentes de Educación Básica, provenientes de escuelas privadas de tres Estados brasileños. Los resultados indicaron que los factores más influyentes en la satisfacción con el trabajo son el afecto positivo y la satisfacción con la vida. No hubo asociación entre las creencias de eficacia (autoeficacia y eficacia colectiva) y la satisfacción en el trabajo. Los profesores de Enseñanza Fundamental presentaron las percepciones más negativas respecto a la docencia. Esta situación tal vez esté determinada por la concurrencia de circunstancias específicas del contexto escolar, que pueden haber contribuído a este resultado, tales como la indisciplina de los estudiantes.
\end{abstract}

Palabras clave: satisfacción en el trabajo, teoría social cognitiva, profesores

\footnotetext{
'This paper is derived from the first author's doctoral dissertation, which was developed under the advice of the second and third authors and was defended in the Graduate Program in Education at the Universidade Federal do Pará. Support: National Council for Scientific and Technological Development (CNPq).

${ }^{2}$ Correspondence address: Universidade Federal do Pará. Graduate Program in Education (PPGED). Rua Augusto Corrêa, n. 1, Guamá, Belém-PA, Brazil. CEP 66.075-110. E-mail: maelyramos@hotmail.com
}

Job satisfaction is an important factor related to human motivation. It manifests as a pleasant condition and a positive emotional state resulting from the individual's evaluation of his/her role (Veldman, van Tartwijk, Brekelmans, \& Wubbels, 2013). The literature in this area indicates that job satisfaction promotes proficiency and well-being among teachers (Van Maele \& Van Houtte, 2012). 
Given the importance of job satisfaction to the educational process, Social Cognitive Theory researchers have investigated its implications amongsamples of teachers (Duffy \& Lent, 2009; Goddard, W. K. Hoy, \& A. W. Hoy, 2000; Klassen, 2010). Some scholars treat this construct globally, investigating it as an independent phenomenon in isolation from other elements of the school context (Van Maele \& Van Houtte, 2012). Other studies have applied integrative models that explorejob satisfactionalongwith other variables (Duffy \& Lent, 2009; Lent et al., 2011).

Duffy and Lent (2009) investigated job satisfaction using an integrative model consisting of six satisfaction predictors: life satisfaction, goal progress, positive affect, efficacyrelevant support, work conditions and self-efficacy. The Social Cognitive Model of Job Satisfaction (SCMJS), proposed by Duffy and Lent (2009), considers elements that are known to influence human behavior and a sense of well-being (extrinsic factors, belief systems and teaching perceptions). However, it is understood that all these factors are explained by teachers' perceptions. This means that in this model, satisfaction levels are influenced by how teachers perceive different aspects of the school environment and by belief systems that determine their motivational states (Lent et al., 2011).

According to this model (Lent et al., 2011), for the teacher to feel satisfied with his/her work, he/she must perceive that: (a) he/she is progressing towards the goals establishedfor the teaching-learning process (goal progress); (b) he/she is receiving the necessary support to perform his/her function and is enjoying favorable work conditions (efficacy-relevant support and work conditions); and (c) he/ she operates in an institutional environment with a pleasant affective atmosphere and experiences positive emotions in his/her relationships with colleagues, superiors, parents and students (positive affect). It is also necessary that the teacher (d) believes that he/she can successfully perform his/her work tasks (self-efficacy) and (e) feels that he/she is fulfilled and happy with his/her life (life satisfaction) (Lent et al., 2011; Lent, Taveira, \& Lobo, 2012).

Belief systems are also fundamental toraising satisfaction levels. Duffy and Lent's SCMJS (2009) includes self-efficacy, that is, the individual's belief in his/her ability to successfully perform his/her tasks (Bandura, 1997). It has been proposed that the higher the teacher's self-efficacy, the greater the likelihood of his/her acting resiliently, overcoming challenges, progressing in his/her career and achieving his/her goals (M. F. H. Ramos, Costa, Pontes, Fernandez, \& Nina, 2014).

Another important belief considered by Social Cognitive Theory is collective teacher efficacy. Studies have found relationships between collective beliefs and satisfaction in teaching work (Caprara, Barbaranelli, Steca, \& Malone, 2006; Klassen, Usher, \& Bong, 2010). Collective teacher efficacy is the shared beliefs among teachers regardingtheir group's ability to perform school tasks and achieve the proposed institutional goals (Bandura, 1997). Both self-efficacy and collective teacher efficacy can be considered beliefs that determine a teacher's job satisfaction (Caprara et al., 2006).
The professional life of a teacher is often stressful, with demands from administrators, colleagues, parents and students aggravated by overwork, political and bureaucratic issues anda lack of recognition, among other factors. These stressors can interfere with job satisfaction and therefore with performance and commitment levels (Klassen, 2010). Studies on job satisfaction and on its main influencing elements, such as efficacy beliefs, work conditions and affective states, therefore have obvious importance.

To this end, the present study aims to identify the dimensions associated with jobsatisfaction amongbasic education teachers based on the Social Cognitive Model of Teacher Job Satisfaction (variables:goal progress, efficacyrelevant support and work conditions, positive affect, life satisfaction, self-efficacy and job satisfaction) ofLent et al. (2011) and the degree of collective teacher efficacy.

\section{Method}

This was a quantitative, exploratory, descriptive and inferential study that aimed to identify associations and similarities between the characteristics of basic education teachers based on the variables of the Social Cognitive Model of Teacher Job Satisfaction (Lent et al., 2011) and oncollective teacher efficacy.

\section{Participants}

The study applied simple and stratified random sampling using a population of 1,079 teachers from three Brazilian states Pará, Amapá and Maranhão operating in a network of private kindergartens, elementary schools and high schools. A sample calculation was performed to ensure that the study's results could be generalized to the target population. The calculation indicated a sample of 495 teachers with a sampling error of $3.31 \%$ to represent the difference between sample estimation and the population. The sample comprised both male $(n=106,21 \%)$ and female $(n=389,79 \%)$ teachers with degrees $(n=264,53 \%)$, specialized certifications $(n=215,44 \%)$ and master degrees $(n=16,3 \%)$.

\section{Instruments}

Three instruments were used for data collection: The Participant Characterization Questionnaire, the School Collective Beliefs scale and the Thoughts on Teaching and School Questionnaire.

The Participant Characterization. Questionnaire comprises 26 items that focus on the participants'information and characteristics, such as experience in teaching, number of students per class, work day, work context infrastructure, age, gender, etc.

School Collective Beliefs Scale (Guerreiro Casanova, 2013) is a tool with an internal consistency of 0.97 that aims to measure teachers 'beliefs about their environment's collective capacity to influence students' academic performance. 
This scale has 12 items and was adapted from TschannenMoran and Barr's (2004) measure of collective teacher efficacy. The version used in this study comprises two dimensions: instructional strategies and student discipline. Its response options range from 1 to 10 points and range from not at all capable to very capable.

Thoughts on Teaching and School Questionnaire (Lent et al., 2011) evaluates the seven variables that constitute the SCMJS and their relationships. The questionnaire was created in the United States and comprises seven Likert-type scales that evaluate each variable in a specific way, as follows: Efficacy-Relevant Support $(\alpha=0.82)-8$ items rated from 1 to 7 (from strongly disagree to strongly agree); Perceived Organizational Support $(\alpha=0.88)-16$ items related to working conditions and rated from 1 to 7 (from strongly disagree to strongly agree); Goal Progress $(\alpha=0.92)-14$ items, with negative and positive options ranging from 1 to 5 and an open question; Life Satisfaction $(\alpha=0.88)$ - 5 items rated from 1 to 7 (from strongly disagree to strongly agree); Job Satisfaction $(\alpha=0.93)$ - 5 items rated from 1 to 7 (from strongly disagree to strongly agree); Positive Affect ( $\alpha=0.96)$ - 9 items rated from 1 to 5 (from very seldom or never to very often); Self-Efficacy $(\alpha=0.90)$ - 12 items rated from 1 to 10 (from not at all capable to very capable). These scales were originally published in English and have been translated into Brazilian Portuguese. Overall, the participants responded to a total of 107 items across all scales and questionnaires.

\section{Procedure}

Data collection. Authorization was requested from the school network's managers to collect the data required for this study. Upon receipt of authorization, data collection began; initial contact was made with the schools' directors in advance to establish the most feasible schedules and locations for implementing the test instruments.

Before the instruments were applied, the participants were informed regardingthe research, the function of the Terms of Free and Informed Consent (TFIC) was explained, information on the Ethics Committee was provided and guidelines for completing the instruments were given. Data collection was conducted face-toface in groups during school hours in the states of Pará, Amapá and Maranhão. The time requiredto complete the instruments ranged from 40 minutes to one hour. All the instruments were self-administered; however, the whole process was attended by the group of researchers responsible for collection.

Data analysis. Two statistical techniques, factor analysis (FA) and correspondence analysis, were usedin the study to investigate the responses of the 495 participating teachers.

Factor analysis (FA) - This technique involves finding ways to condense the information contained in the original variables into a smaller set of statistical elements (factors) with a minimal loss of information. It involves the search for and evaluation of a set of variables to identify common dimensions of variability (Morettin \& Bussab, 2013). Factor analysis was used to construct indices (factors by variable) relatedto the investigated elements and an overall index relatedto the perception of teaching, which brought together the SCMJS and the collective effectiveness dimensions.

The following steps were completed duringthe construction of indices for variables relatedto the participants' perceptions of teaching: (a) normality test and identification of whether outliers (discrepant values) existed in the data set; (b) analysis of the correlation matrix: correlations were required to be equal to or greater than 0.30 ; (c) KaiserMeyer-Olkin (KMO) statistics to establish whether the data weresuitable for FA; (d) the Bartlett sphericity test; (e) sample adequacy measurement (SAM) to verify that the variables studied were suitable for use withthe FA technique; (f) Kaiser criterion to determine the number of extracted factors, i.e., the number of equations necessary to construct the indices; (g) Varimax method to rotate the values extracted for each factor to maximize the information for each element used to construct the indices; (h) calculation of factorial scores (indexes) for each teacher by multiplying the individual values that each teacher assigned to each question by factor weightings; (i) standardization of the values obtained so that they could be evaluated on a scale of 0 to 1 or 0 to $100 \%$ (Morettin \& Bussab, 2013). In all phases, the variables under study proved adequate for FA, so it was possible to calculate all the indices. Statistic a version 6.0 and SPSS-20 software were used for FA.

Correspondence analysis - Correspondence analysis is a statistical technique used to examine associations or similarities between qualitative or continuous categorical variables. It is an interdependence technique that aims to optimally representthe structure of the observed data. Its main characteristic is the reduction of the data to be analyzed by the researcher with minimal loss of information bytransforming the rows and columns of tables into corresponding units, thus facilitating joint representation of the data (Morettin \& Bussab, 2013). Correspondence analysis was used to find and characterize groups (clusters) according to the participants' factor scores in relation to the investigated variables. In the correspondence analysis, associations between categories were considered significant when the confidence coefficient value $(\gamma)$ was $70 \%$ or higher (Morettin \& Bussab, 2013). Correspondence analysis was performed using version 6.0 of the Statistica application. In all tests, $\alpha=5 \%(p \leq 0.05)$ was adopted for the rejection of the null hypothesis.

The following steps are considered for correspondence analysis: (a) The chi-square test $\left(\chi^{2}\right)$ is used to verify the existence of dependency between study variables. The hypotheses tested are $\mathrm{H} 0$ : the variables are independent and $\mathrm{H} 1$ : the variables are dependent. The null hypothesis (H0) must be rejected for the correspondence analysis to proceed; (b) $\beta$ criteria are calculated to verify the dependence between the variable categories; (c) The inertia percentage - the variation explained by each dimension - is calculated; (d) The confidence coefficient $(\gamma)$ is calculated to determine 
the probability of a variable category beingassociated with another; to that end, a procedure based on residuals is used that considers the difference between expected and observed frequencies (E. M. L. S. Ramos, Almeida \& Araujo, 2008).

Variable classification - Two groups of variables were considered for the proposed analyses: (a) perceptions about teaching variables, based on the seven SCMJS dimensions (self-efficacy, job satisfaction, life satisfaction, work conditions, goal progress, positive affect, and efficacyrelated support) and collective teacher efficacy, and (b) the education level variable, namely, the school level at which the teacher operated (kindergarten, elementary school, high school).

Teacher classification - The teachers were then classified into three distinct groups for each separate SCMJS component. This classification, based on the sample quartiles theory, was applied only to SCMJS and collective efficacy variables that showedsignificant associations in the correspondence analysis. It is assumed that the first quartile - $\mathrm{Q}_{1 / 4}$ (lower quartile) - includes $25 \%$ of the ordered sample $\left(25^{\text {th }}\right)$; the second quartile $\mathrm{Q}_{2 / 4}$ (median) is the value at which $50 \%$ of the sample is included $\left(50^{\text {th }}\right)$; the third quartile, $\mathrm{Q}_{3 / 4}$, is the value at which $75 \%$ of the ordered sample ( $\left.75^{\text {th }}\right)$ is included, and the fourth quartile, $\mathrm{Q}_{4 / 4}$ (upper quartile), is the maximum value and represents the top $25 \%$ of the sample (Morettin \& Bussab, 2013).

The participant groups were organized as follows: Group 1/1st quartile - Teachers with scores from 0 to $25 \%$ (the teacher group with the lowest scores); Group 2/2nd and 3rd quartiles - Teachers scoring 26-75\% (moderate scores); Group 3/4th quartile - Teachers with scores of $76-100 \%$ (highest scores).

\section{Ethical Considerations}

This study is part of the macro Project Teaching Effectiveness Beliefs and Satisfaction in School Work that was submitted to the Ethics Committee of Ethics Committee of the Nucleus of Tropical Medicine (NMT) from Universidade Federal do Pará (UFPA) and approved in accordance with protocol number 766.978 .

\section{Results}

The results are presented in the following order: (a) Associations based on SCMJS dimensions, exploring the relationship between job satisfaction and the other six model components; (b) associations based on collective efficacy and SCMJS, evaluating whether there is any relationship between collective efficacy and the model components; (c) associations based on the teaching perceptions index and educational levels (Kindergarten, Elementary School and High School) to determine the teachers' perceptions according to the level of school in which they work.

\section{Associations based on SCMJS dimensions}

The correspondence analysis indicated associations and similarities between the study participants based on characteristics established by Lent et al. (2011) SCMJS dimension indices, namely, self-efficacy, life satisfaction, job satisfaction, goal progress, work conditions, efficacyrelatedsupport, and positive affect. Table 1 shows the resulting statistics after the correspondence analysis technique was applied to the seven SCMJS dimensions.

Table 1

Test Results (Correspondence Analysis) to Verify the Dependency of Positive Affect, Efficacy-RelatedSupport, Life Satisfaction and Job Satisfaction Indices

\begin{tabular}{|c|c|c|c|c|c|c|}
\hline Variables & $\chi^{2}$ & Rows & Columns & $\beta$ & Inertia & $p$ \\
\hline $\begin{array}{l}\text { Positive Affect Index/Job } \\
\text { Satisfaction }\end{array}$ & 13.61 & 3 & 3 & 4.81 & 100.00 & 0.009 \\
\hline $\begin{array}{l}\text { Efficacy-RelatedSupport Index/ } \\
\text { Job Satisfaction }\end{array}$ & 13.37 & 3 & 3 & 4.69 & 100.00 & 0.010 \\
\hline $\begin{array}{l}\text { Life Satisfaction Index/Job } \\
\text { Satisfaction }\end{array}$ & 35.38 & 3 & 3 & 15.69 & 100.00 & 0.000 \\
\hline
\end{tabular}

Table 1 shows only the indices of variables with significant correlations. Note that only three SCMJS dimensions were related to teacher job satisfaction: positive affect, efficacy-relatedsupport and life satisfaction. The descriptive level values $(p)$ are lower than the 0.05 significance level $(5 \%)$, and the beta criterion $(\beta)$ values are greater than 3. Moreover, the sum of the inertia percentages indicates that more than $70 \%$ of the information was returned by the correspondence analysis. All conditions required for use of the correspondence analysis technique were therefore satisfied.

The indices for self-efficacy, work conditions and goal progress variables were not associated with job satisfaction. Therefore, it was only possible to identify participant characteristics in relation to the SCMJS for the three dimensions that were significantly correlated with job satisfaction. Table 2 shows the probabilities of these factors in the sample of teachers. 
Ramos, M. F. H., Pontes, F. A. R., Silva, S. S. C., Ramos, E. M. L., Casanova, D. C. G., Azzi, R. G. (2018). Teacher Job Satisfaction.

Table 2

Probability Applied to Job Satisfaction, Positive Affect, Efficacy-RelatedSupport and Life Satisfaction Indices

\begin{tabular}{|c|c|c|c|c|c|c|c|c|c|}
\hline \multirow{2}{*}{ Job Satisfaction } & \multicolumn{3}{|c|}{ Positive Affect } & \multicolumn{3}{|c|}{ Efficacy-RelatedSupport } & \multicolumn{3}{|c|}{ Life Satisfaction } \\
\hline & Low & Moderate & High & Low & Moderate & High & Low & Moderate & High \\
\hline Low & $100.00 * *$ & $(0.00)$ & $(0.00)$ & $(0.00)$ & $(0.00)$ & $(0.00)$ & $99.99 * *$ & $(0.00)$ & $(0.00)$ \\
\hline Moderate & $(0.00)$ & $88.19 * *$ & $(0.00)$ & $(0.00)$ & $(0.00)$ & $(0.00)$ & $(0.00)$ & 1.78 & $54.78 *$ \\
\hline High & $(0.00)$ & $(0.00)$ & $100.00 * *$ & $(0.00)$ & $(0.00)$ & $(0.00)$ & $(0.00)$ & $83.95 * *$ & $66.68 * * *$ \\
\hline
\end{tabular}

Note. *Moderately significant probabilities, $50.00 \geq \gamma$ x $100 \geq 69.99 \%$. **Strongly significant probabilities, $\gamma$ x $100 \geq 70 \%$.

Given that the correspondence analysis was conducted to group the sample elements according to their similarities, it was noted that the SCMJS, specifically the job satisfaction dimension, could be used as a base to characterize the three previously described groups of teachers: (1) the high satisfaction scores group; (2) the moderate scores group; and (3) the low scores group.

Regarding the study sample, the teachers who were most satisfied with their jobs were those who operated in a more emotionally positive environment and who were very satisfied or moderately satisfied with their lives. It was also found that teachers who were less satisfied with their jobs served in an environment with less positive affect and were less satisfied with their lives. In comparison, the teachers who were moderately satisfied with their jobs had a moderate perception of positive affect and had the highest life satisfaction scores.

\section{Associations based on collective teacher efficacy and SC- MJS dimensions}

The same processes were used to verify the associations and similarities between the participants in terms ofcollective teacher efficacy and SCMJS dimensions (Table 3).

Table 3

Result of Tests (Correspondence Analysis) to Verify the Dependency ofthe Indices: Collective Efficacy and SCMJS Dimensions

\begin{tabular}{|c|c|c|c|c|c|c|}
\hline Variables & $\chi^{2}$ & Rows & Columns & $\beta$ & Inertia & $p$ \\
\hline $\begin{array}{l}\text { Collective Efficiency Index/ } \\
\text { Teaching Beliefs Index }\end{array}$ & 81.92 & 3 & 3 & 38.96 & 100.00 & 0.00 \\
\hline $\begin{array}{l}\text { Collective Efficiency Index/ } \\
\text { Positive Affect Index }\end{array}$ & 10.34 & 3 & 3 & 3.17 & 100.00 & 0.031 \\
\hline $\begin{array}{l}\text { Collective Efficiency Index/ } \\
\text { Efficacy-RelatedSupport } \\
\text { Index }\end{array}$ & 14.55 & 3 & 3 & 5.28 & 100.00 & 0.006 \\
\hline $\begin{array}{l}\text { Collective Efficiency Index/ } \\
\text { Goal Progress Index }\end{array}$ & 9.99 & 3 & 3 & 3.00 & 100.00 & 0.044 \\
\hline $\begin{array}{l}\text { Collective Efficiency Index/ } \\
\text { Life Satisfaction Index }\end{array}$ & 10.00 & 3 & 3 & 3.00 & 100.00 & 0.041 \\
\hline
\end{tabular}

The correspondence analysis indicated that collective efficacy was significantly correlated with the following SCMJS dimensions: self-efficacy, positive affect, efficacy-relatedsupport, goal progress, and life satisfaction. In this study, collective efficacy did not correlate significantly with job satisfaction $(p=$ $0.07)$ or work conditions $(p=0.09)$. It should be emphasized that relationships were considered significant at $p \leq 0.05$.
As in the previous analyses, all the conditions for using the correspondence analysis technique were satisfied. In this case, the sum of the inertia percentages indicated that $100 \%$ of the information was returned by the correspondence analysis. Consequently, the probability of these factors occurring in the sample of teachers was analyzed (Table 4). 
Table 4

Probability Applied to Collective Efficacy, Self-Efficacy, Positive Affect, Efficacy-RelatedSupport, Goal Progress and Life Satisfaction Indices

\begin{tabular}{|c|c|c|c|}
\hline \multirow{3}{*}{ Self-Efficacy } & \multicolumn{3}{|c|}{ Collective Efficacy } \\
\hline & \multirow[t]{2}{*}{ Low } & \multirow[t]{2}{*}{ Moderate } & \multirow[t]{2}{*}{ High } \\
\hline & & & \\
\hline Low & $100.00 * *$ & $(0.00)$ & $(0.00)$ \\
\hline Moderate & $(0.00)$ & $94.97 * *$ & $(0.00)$ \\
\hline High & $(0.00)$ & $(0.00)$ & $99.99 * *$ \\
\hline \multicolumn{4}{|c|}{ Positive Affect } \\
\hline Low & $95.03 * *$ & $(0.00)$ & $(0.00)$ \\
\hline Moderate & $(0.00)$ & 43.46 & $(0.00)$ \\
\hline High & $(0.00)$ & $(0.00)$ & $88.56 * *$ \\
\hline \multicolumn{4}{|c|}{ Efficacy-Related Support } \\
\hline Low & $96.78 * *$ & $(0.00)$ & $(0.00)$ \\
\hline Moderate & $(0.00)$ & $55.23 *$ & $(0.00)$ \\
\hline High & $(0.00)$ & $(0.00)$ & $96.38 * *$ \\
\hline \multicolumn{4}{|c|}{ Goal Progress } \\
\hline Low & $84.56 * *$ & $(0.00)$ & $(0.00)$ \\
\hline Moderate & 21.30 & 23.46 & $(0.00)$ \\
\hline High & $(0.00)$ & $(0.00)$ & $92.00 * *$ \\
\hline \multicolumn{4}{|c|}{ Life Satisfaction } \\
\hline Low & 40.18 & 19.32 & $(0.00)$ \\
\hline Moderate & $75.40 * *$ & $(0.00)$ & $(0.00)$ \\
\hline High & $(0.00)$ & 38.63 & $84.06 * *$ \\
\hline
\end{tabular}

Note. *Moderately significant probabilities, $50.00 \geq \gamma$ x $100 \geq 69.99 \%$. **Strongly significant probabilities, $\gamma$ x $100 \geq 70 \%$.

Using the results of the performed analysis and teachers' collective beliefs indexes as the central axis of this stage ofthe study, it was possible to categorize the teachers into three groups: (1) those with low collective efficacy scores; (2) those with moderate collective efficacy scores; and (3) those with high collective efficacy scores. The teachers with high collective efficacy levels also showed high scores for self-efficacy, positive affect, efficacy-related support, goal progress and life satisfaction.

The opposite relationships were also detected: the teacher's with the lowest collective efficacy levels also had the lowest scores for four of the five positively correlated SCMJS indices (the exception was life satisfaction). These results indicate that teachers with low collective efficacy beliefs had moderate life satisfaction levels.

The teachers who had moderate levels of collective efficacy also showed moderate self-efficacy and collective efficacy support scores. Overall, although collective efficacy was not linked directly to job satisfaction, it was significantly related to five SCMJS dimensions (self-efficacy, positive affect, efficacy-relevant support, goal progress and life satisfaction), suggesting that these dimensions may be associated with the level of collective teacher efficacy.

\section{Associations based on the overall Perceptions of Teaching Index and basic education teaching levels}

To complete the study, an overall index was constructed using information fromthe eight variables studiedin this research (job satisfaction, life satisfaction, self-efficacy, collective efficacy, goal progress, positive affect, work conditions and efficacy-related support). This index was called the Perceptions of Teaching Index because it explored aspects that were based on the teachers' perceptions of these factors within the school context. A correspondence analysis was then performed to identify associations between this overall index and basic education level (kindergarten, elementary school and high school).

Descriptive values $(p)$ were lower than the 0.05 significance level $(5 \%)$, and $\beta$ wasgreater than $3(\beta=4.81)$. The null hypothesis was rejected $\left(\chi^{2}=13.61\right)$. In this case, the sum of the inertia percentages also indicated that $100 \%$ of information was returned by the correspondence analysis. The statistics resulting from the correspondence analysis suggested the likelihood of an association between the Perceptions of Teaching Index and the education level at which the teacher works (Table 5).

Table 5

Probability Applied to Overall Perceptions of Teaching Index and Education Level

\begin{tabular}{lccc}
\hline \multirow{2}{*}{ Education Level } & \multicolumn{4}{c}{ Overall Perceptions of Teaching Index } \\
\cline { 2 - 4 } & Low & Moderate & High \\
\hline Kindergarten & $(0.00)$ & $\mathbf{7 4 . 5 9 *}$ & $(0.00)$ \\
Elementary & $\mathbf{7 8 . 5 0 *}$ & $(0.00)$ & $(0.00)$ \\
School & $(0.00)$ & $(0.00)$ & $\mathbf{9 9 . 9 9 *}$ \\
High School & . &
\end{tabular}

Note. ${ }^{*}$ Strongly significant probabilities, $\gamma$ x $100 \geq 70 \%$.

Three clusters of teachers were defined based on the school level at which they worked (kindergarten, elementary school and high school) to identify probabilities. It should be emphasized that all the probabilities investigated in this phase of the study were strongly significant ( $\gamma \times 100 \geq 70 \%)$.

Teachers working in kindergartens showed moderate teaching perception scores, while those working in high schools had the best perceptions. Elementary school teachers, however, had the worst perceptions. This suggests that in reference to the collected sample, teachers atthis level (a) had the lowest efficacy beliefs (both personal and collective); (b) were the least satisfied with life and work; (c) felt the least supported by colleagues and superiors; (d) perceived the least progress toward achieving their proposed goals; (e) felt that they worked in an environment with less positive affect; 
(f) believed they do not work under satisfactory work conditions. Conversely, kindergarten and high school teachers produced moderate to high scores on this index, which concentrates the eight dimensions investigated in this research.

\section{Discussion}

\section{Life and job satisfaction and positive affect}

The results of this study indicate that among the six secondary variables of Lent et al.'s SCMJS (2011), only two dimensions were associated with job satisfaction: life satisfaction and positive affect. Life satisfaction is a wellbeing indicator that influences all areas, including education, health, leisure and work. It is believed that good life satisfaction levels can result in better performance at work, as this is an important part of the individual's life (Ignat\&Clipa, 2012). It is understood that this type of satisfaction is an important resource in terms of teachers feelingfulfilled intheirwork. The literature in the area claims that the relationship between these two factors is bidirectional; they influence each other. This reveals a great dealabout the importance of work in an individual's life and how feelings of professional dissatisfaction can have a negative impact on the teacher's overall well-being (Lent et al., 2011).

Positive affect is another factor that has been strongly related to job satisfaction (Duffy \& Lent, 2009; Lent et al., 2011, 2012). Moè, Pazzaglia and Ronconi (2010) concluded that for teachers to experience job satisfaction, it is necessary to develop an affectively positive atmosphere in schools. This means that when teachers feel good in their work environment and experience warmth, empathy, affection and positive emotions, satisfaction levels tend to rise.

\section{Collective efficacy and SCMJS dimensions}

The collective efficacy variable was not associated with job satisfaction and work conditions; however, it was related to the model's other five dimensions (self-efficacy, positive affect, efficacy-relevant support, goal progress and life satisfaction). It should be emphasized that we decided to investigate the relationship between collective efficacy and job satisfaction using the SCMJS because previous research reported an association between the two (Viel-Ruma, Houchins, Jolivette, \& Benson, 2010).

The study of the relationship between collective efficacy and self-efficacy is well established as highly important in this area of knowledge: According to Social Cognitive Theory, both constructs form the basis of human agency and act as strong motivational elements of teacher's behavior (Bandura, 1997; M. F. H. Ramos et al., 2014). Recent research has indicated that there are significant relationships between self-efficacy and collective efficacy (Goddard et al., 2000; Viel-Rumaet al., 2010): Both are associated with improved teacher and student performance. For this reason, the study of these factors is crucial for improving teaching and learning (E. M. Skaalvik \& S. Skaalvik, 2007).
To the best of our knowledge, no previous research has explored associations between Lent et al.'s SCMJS dimensions (2011) and collective teacher efficacy. The results presented here may therefore provide the basis for further studies. It was found that an affectively positive work environment, aperception of being supported, progression toward achieving one's goals and a sense of personal fulfillment are elements that may contribute to an increase in collective teacher efficacy levels.

\section{Education level and overall}

The characterization and comparison of groups of teachers established according to basic education level (kindergarten, elementary school and high school) and the overall Perceptions of Teaching Index revealed that elementary school teachers had the most negative perceptions of efficacy beliefs (personal and collective), work and life satisfaction, goal progress, work conditions, efficacy-relatedsupport and positive affect. It is understood that elementary school students (lower - ages 6-12 years; higher - ages 13 to 16 years) experience the transition from childhood to adolescence and that this period may be associated with a higher incidence of a lack of discipline in school and conflicts with teachers and colleagues (M. F. H. Ramos et al., 2014). It is possible that this context influences teachers' perceptions of teaching. Other contextual problems may also be associated with this education level, including school management, work conditions, teacher training and public policy. More research is needed to identify the reasons for the negative perceptions of the teachers at this level in our sample.

Because of the type of sample collected, the results of this research can be generalized to the target population. A limitation of this study is that it investigated teachers from a private school network; therefore, it is suggested that further research be applied to public school teacher samples.

\section{References}

Bandura, A. (1997). Self-efficacy: The exercise of control. New York, NY: Worth.

Caprara, G. V., Barbaranelli, C., Steca, P., \& Malone, P. S. (2006). Teachers' self-efficacy beliefs as determinants of job satisfaction and students' academic achievement: A study at the school level. Journal of School Psychology, 44(6), 473-490. doi:10.1016/j.jsp.2006.09.001

Duffy, R. D., \& Lent, R. W. (2009). Test of a social cognitive model of work satisfaction in teachers. Journal of Vocational Behavior, 75(2), 212-223. doi: 10.1016/j. jvb.2009.06.001

Guerreiro Casanova, D. C. (2013). Crenças de eficácia de gestores escolares e de docentes do ensino médio paulista (Tese de doutorado não publicada). Universidade Estadual de Campinas, Campinas, SP. 
Goddard, R. D., Hoy, W. K., \& Hoy, A. W. (2000). Collective teacher efficacy: Its meaning, measure, and impact on student achievement. American Educational Research Journal, 37(2), 479-507. Doi: 10.3102/00028312037002479

Ignat, A. A., \& Clipa, O. (2012). Teachers' life satisfaction, job satisfaction and their emotional intelligence. Procedia - Social and Behavioral Sciences, 33, 498-502. doi:10.1016/j.sbspro.2012.01.171

Klassen, R. M. (2010). Teacher stress: The mediating role of collective efficacy beliefs. The Journal of Educational Research, 103(5), 342-350. doi:10.1080/00220670903383069

Klassen, R. M., Usher, E. L., \& Bong, M. (2010). Teachers' collective efficacy, job satisfaction, and job stress in crosscultural context. The Journal of Experimental Education, 78(4), 464-486. doi:10.1080/00220970903292975

Lent, R. W., Nota, L., Soresi, S., Ginevra, M. C., Duffy, R. D., \& Brown, S. D. (2011). Predicting the job and life satisfaction of Italian teachers: Test of a social cognitive model. Journal of Vocational Behavior, 79(1), 91-97. doi:10.1016/j.jvb.2010.12.006

Lent, R. W., Taveira, M. C., \& Lobo, C. (2012). Two tests of the social cognitive model of well-being in Portuguese college students. Journal of Vocational Behavior, 80(2), 362-371. doi:10.1016/j.jvb.2011.08.009

Moè, A., Pazzaglia, F., \&Ronconi, L. (2010). When being able is not enough: The combined value of positive affect and self-efficacy for job satisfaction in teaching. Teaching and Teacher Education, 26(5), 1145-1153. doi:10.1016/j. tate.2010.02.010

Morettin, P. A., \& Bussab, W. O. (2013). Estatística básica [Basic statistics] (8aed.). São Paulo, SP: Saraiva.

Ramos, E. M. L. S., Almeida, S. S., \& Araújo, A. R. (Orgs.). (2008). Segurança pública: Uma abordagem estatística e computacional [Public safety: A statistical and computational approach]. Belém, PA: Editora Universitária EDUFPA.

Ramos, M. F. H., Costa, S. S., Pontes, F. A. R., Fernandez, A. P. O., \& Nina, K. C. F. (2014). Collective teacher efficacy beliefs: A critical review of the literature. International Journal of Humanities and Social Science, 4(7), 179-188. Retrieved from http:/www.ijhssnet.com/journals/Vol_4_ No_7_1_May_2014/23.pdf

Skaalvik, E. M., \&Skaalvik, S. (2007). Dimensions of teacher self-efficacy and relations with strain factors, perceived collective teacher efficacy, and teacher burnout. Journal of Educational Psychology, 99(3), 611625. doi:10.1037/0022-0663.99.3.611

Tschannen-Moran, M., \& Barr, M. (2004). Fostering student learning: The relationship of collective teacher efficacy and student achievement. Leadership and Policy in Schools, 3(3), 189-209. Doi:10.1080/15700760490503706
Van Maele, D., \& Van Houtte, M. (2012). The role of teacher and faculty trust in forming teachers' job satisfaction: Do years of experience make a difference? Teaching and Teacher Education, 28(6), 879-889. doi:10.1016/j.tate.2012.04.001

Veldman, I., van Tartwijk, J., Brekelmans, M., \& Wubbels, T. (2013). Job satisfaction and teacher-student relationships across the teaching career: Four case studies. Teaching and Teacher Education, 32, 55-65. doi:10.1016/j. tate.2013.01.005

Viel-Ruma, K., Houchins, D., Jolivette, K., \& Benson, G. (2010). Efficacy beliefs of special educators: The relationships among collective efficacy, teacher selfefficacy, and job satisfaction. Teacher Education and Special Education: The Journal of the Teacher Education Division of the Council for Exceptional Children, 33(3), 225-233. doi:10.1177/0888406409360129

Maély Ferreira Holanda Ramos is a Professor Doctor in the Faculty of Education and Graduate Program in Education at Universidade Federal do Pará, Brazil.

Fernando Augusto Ramos Pontes is a Professor Doctor in the Graduate Program in Behavior Theory and Research in Education at Universidade Federal do Pará, Brazil.

Simone Souza da Costa Silva is a Professor Doctor in the Graduate Program in Behavior Theory and Research in Education at Universidade Federal do Pará, Brazil.

Edson Marcos Leal Ramos is Coordinator of the PostGraduation Program in Public Security at Universidade Federal do Pará, Brazil.

Daniela Couto Guerreiro Casanova is a Professor Doctor at the Center for Cognitive Social Theory and Educational Practices at Universidade Estadual Paulista, Brazil.

Roberta Gurgel Azzi is a Professor in the Faculty of Education at Universidade Estadual de Campinas, Brazil.

Received: Sept. 25, 2015

1st Revision: Mar. 21, 2016

Approved: May 26, 2016

How to cite this article:

Ramos, M. F. H., Pontes, F. A. R., Silva, S. S. C., Ramos, E. M. L., Casanova, D. C. G., \& Azzi, R. G. (2018). Characterization of basic education teachers from the satisfaction of cognitive social model at work. Paidéia (Ribeirão Preto), 28, e2811. doi: http://dx.doi.org/10.1590/1982-4327e2811 